\title{
Flea beetles (Coleoptera, Chrysomelidae, Alticinae) on genetically modified linseed (Linum usitatissimum L.)
}

\section{Pchełki (Coleoptera, Chrysomelidae, Alticinae) zasiedlające genetycznie modyfikowany len oleisty (Linum usitatissimum L.)}

\author{
Michał Hurej ${ }^{1}$, Radosław Ścibior ${ }^{2}$, Jacek P. Twardowski ${ }^{1}{ }^{*}$, Andrzej Kotecki $^{3}$
}

\begin{abstract}
Summary
Genetically modified plants of linseed (Linum usitatissimum L.) with increased contents of secondary metabolites may affect the relationship between a plant and a pest. The aim of this study was to evaluate the effect of two types of genetically modified plants of linseed, variety Linola, on the species composition, abundance, seasonal dynamics and number of damages caused by flea beetles (Coleoptera, Chrysomelidae, Alticinae). The study was conducted in 2011-2013, at the experimental station in Pawłowice. The experiments were carried out on the genetically modified type of linseed overproducing flavonoids, the type overproducing glucose derivatives of phenylpropanoid and the control plants. The number of damages caused by these beetles on whole plants was determined. Within three years of research 11 species of flea beetles were identified. Aphthona euphorbiae (Schrank, 1781) was the most abundant species, regardless of the every treatment in each experimental year. Longitarsus parvulus (Paykull, 1799) occurred less frequently. There was no clear effect of the genetic modification of linseed on the species composition, abundance and population dynamics of flea beetles and number of damages caused by these beetles.
\end{abstract}

Key words: genetically modified linseed; flea beetles; Aphthona euphorbiae; Longitarsus parvulus; abundance

\section{Streszczenie}

Genetycznie modyfikowane rośliny Inu oleistego o zwiększonej zawartości wtórnych metabolitów mogą wpływać na powiązania pomiędzy rośliną a szkodnikiem. Celem prezentowanych badań była ocena wpływu dwóch typów genetycznie modyfikowanych roślin Inu oleistego, odmiana Linola, na skład gatunkowy, liczebność, dynamikę występowania oraz na liczbę uszkodzeń powodowanych przez pchełki. Badania prowadzono w latach 2011-2013, w Rolniczym Zakładzie Doświadczalnym w Pawłowicach. W doświadczeniu wykorzystano genetycznie modyfikowany typ Inu oleistego nadprodukujący flawonoidy, typ nadprodukujący glukozowe pochodne fenylopropanoidów oraz rośliny kontrolne Inu. Określano liczbę uszkodzeń powodowanych przez te chrząszcze w postaci wyżerek na całej roślinie Inu. W ciągu trzech lat badań na roślinach Inu oleistego oznaczono 11 gatunków pchełek. W każdym roku zdecydowanie najliczniejszym gatunkiem, niezależnie od każdej kombinacji, był Aphthona euphorbiae (Schrank, 1781). W znacznie mniejszym nasileniu występował Longitarsus parvulus (Paykull, 1799). Nie stwierdzono jednoznacznego wpływu modyfikacji genetycznej Inu oleistego na skład gatunkowy, liczebność i dynamikę populacji pchełek oraz liczbę uszkodzeń powodowanych przez te chrząszcze.

Słowa kluczowe: genetycznie modyfikowany len oleisty; pchełki; Aphthona euphorbiae; Longitarsus parvulus; liczebność

\footnotetext{
Uniwersytet Przyrodniczy we Wrocławiu, Katedra Ochrony Roślin

C.K. Norwida 25, 50-375 Wrocław

${ }^{2}$ Uniwersytet Przyrodniczy w Lublinie, Katedra Zoologii, Ekologii Zwierząt i Łowiectwa

Akademicka 13, 20-950 Lublin

${ }^{3}$ Uniwersytet Przyrodniczy we Wrocławiu, Katedra Szczegółowej Uprawy Roślin

C.K. Norwida 25, 50-375 Wrocław

*corresponding author: jacek.twardowski@up.wroc.pl
} 


\section{Wstęp / Introduction}

Genetycznie modyfikowane rośliny mają coraz większe znaczenie gospodarcze i są uprawiane na świecie na dużą skalę (bawełna, kukurydza, rzepak ozimy, ryż, soja, burak cukrowy). Powszechne modyfikacje roślin dotyczą takich cech, jak: odporność na szkodniki oraz patogeniczne grzyby i wirusy, tolerancja na herbicydy oraz odporność na niekorzystne warunki środowiska. Duże praktyczne znaczenie mają również modyfikacje genetyczne, których celem jest poprawa cech jakościowych roślin uprawnych (Nap i wsp. 2003; Linkiewicz i wsp. 2012). Przykładem modyfikacji cech jakościowych jest len, odmiana Linola, nadprodukujący flawonoidy (Zuk i wsp. 2011) oraz len tej samej odmiany nadprodukujący glukozowe pochodne fenylopropanoidów (Czemplik i wsp. 2012). Flawonoidy i inne fenylopropanoidy wykazują dużą aktywność biologiczną i z tego powodu mają korzystny wpływ na zdrowie człowieka (Korkina 2007). To korzystne oddziaływanie związane jest głównie $\mathrm{z}$ ich właściwościami antyoksydacyjnymi (Stolarzewicz i wsp. 2013). Flawonoidy jako wtórne metabolity wpływają na wzrost i rozwój roślin. Jednocześnie chronią one rośliny przed czynnikami stresowymi, w tym przed patogenami i szkodnikami. Na owady mogą działać jako antyfidanty, czynniki obniżające wartość pobieranego pokarmu lub nawet jako toksyny (Simmonds i wsp. 1990; Simmonds 2003; Treutter 2006; War i wsp. 2012).

Pchełka lnowa Aphthona euphorbiae (Schrank, 1781) i długostopka lnowa Longitarsus parvulus (Paykull, 1799), wymieniane są przez wielu autorów jako główne szkodniki lnu oleistego i włóknistego w Europie (Fritzsche i Lehmann 1975; Lewartowski i Piekarczyk 1978; Horak 1991; Ferguson i wsp. 1997; Heller i wsp. 2006; Heller 2013). Oba gatunki mogą żerować razem na lnie, jednak $A$. euphorbiae rozwija się $\mathrm{w}$ szerszym zakresie temperatury i wilgotności w porównaniu do L. parvulus. Pchełka lnowa preferuje ciepłą i suchą pogodę, która zwykle jest zabójcza dla jaj, larw i poczwarek długostopki lnowej. Z kolei długostopka lnowa preferuje chłodne oraz wilgotne warunki i bardzo często jest gatunkiem dominującym w czasie chłodnej i deszczowej wiosny (Żurańska 1965a, b; Wise i Soroka 2003).

Genetycznie modyfikowane rośliny lnu oleistego o zwiększonej zawartości wtórnych metabolitów mogą wpływać na powiązania pomiędzy rośliną a szkodnikiem.

Celem prezentowanych badań była ocena wpływu dwóch typów genetycznie modyfikowanych roślin lnu oleistego na skład gatunkowy, liczebność, dynamikę występowania oraz na wielkość uszkodzeń powodowanych przez pchełki.

\section{Materiały i metody / Materials and methods}

Badania prowadzono w latach 2011-2013, na terenie Rolniczego Zakładu Doświadczalnego w Pawłowicach, należącego do Uniwersytetu Przyrodniczego we Wrocławiu $\left(51^{\circ} 1737^{\prime} \mathrm{N}, 17^{\circ} 1176^{\prime} \mathrm{E}\right)$. W doświadczeniu wykorzystano genetycznie modyfikowany typ lnu oleistego, odmiana Linola, nadprodukujący flawonoidy (Zuk i wsp.
2011) (typ 1), len tej samej odmiany nadprodukujący glukozowe pochodne fenylopropanoidów (Czemplik i wsp. 2012) (typ 2) oraz rośliny kontrolne lnu zawierające typową dla tej odmiany zawartość fenylopropanoidów (typ 3). Rośliny uprawiano na poletkach o wielkości $15 \mathrm{~m}^{2}$ $(10 \mathrm{~m} \times 1,5 \mathrm{~m})$. Odstępy między poletkami wynosiły 0,3 metra i były mechanicznie utrzymywane w ugorze. Doświadczenie założono w układzie losowanych podbloków w czterech powtórzeniach. W każdej kombinacji wysiewano po 600 nasion $/ \mathrm{m}^{2}$.

Pchełki odławiano co drugi tydzień przy pomocy czerpaka entomologicznego o średnicy $40 \mathrm{~cm}$. Każda próba składała się z 10 zagarnięć czerpakiem wykonanych w środkowej części każdego poletka. Materiał entomologiczny przewożono do laboratorium, konserwowano w 75\% alkoholu etylowym, a następnie segregowano, liczono i oznaczano do gatunku korzystając z kluczy Mohra (1966) i Warchałowskiego (1978). Nazwy gatunkowe Chrysomelidae przyjęto za Borowcem i wsp. (2011). Liczbę uszkodzeń powodowanych przez pchełki w postaci wyżerek na liściach, łodygach i torebkach lnu liczono raz w tygodniu na 50 kolejnych roślinach rosnących w środkowym rzędzie każdego poletka. Obserwacje takie prowadzono w ciągu całego okresu wegetacyjnego Linum usitatissimum

Liczebność pchełek oraz ich uszkodzeń odnotowanych w poszczególnych kombinacjach doświadczenia porównywano statystycznie, korzystając $\mathrm{z}$ analizy wariancji (ANOVA, $\mathrm{p} \leq 0,05$ ) oraz testu parametrycznego Tukeya (RIR). Obliczeń dokonano wykorzystując program STATISTICA v. 12.0.

\section{Wyniki i dyskusja / Results and discussion}

Liczebność i skład gatunkowy pchełek. W 2011 roku wykonano 6 odłowów przy użyciu czerpaka entomologicznego. Łącznie, w trzech kombinacjach, odnotowano 2729 pchełek oznaczonych do 5 gatunków (tab. 1). Nie stwierdzono istotnych różnic w liczbie odłowionych owadów w zależności od typu $\operatorname{lnu}(\mathrm{F}=0,363$, df $=2$, $\mathrm{p} \leq 0,696)$. W każdej kombinacji zdecydowanie najliczniejszym gatunkiem był $A$. euphorbiae, który stanowił od $89,7 \%$ (typ 3) do 91,9\% (typ 1 i typ 2) wszystkich pchełek odłowionych w omawianym roku. Wśród pozostałych gatunków pchełek najliczniej odławiany był tylko L. parvulus. Procentowy udział tego gatunku był najwyższy $(10,2 \%)$ na roślinach o typowej dla odmiany Linola zawartości fenylopropanoidów (typ 3). Przedstawiciele trzech pozostałych gatunków występowali sporadycznie i nie we wszystkich kombinacjach.

W 2012 roku, w 6 odłowach, we wszystkich kombinacjach odłowiono łącznie 1543 pchełki, spośród których oznaczono 9 gatunków (tab. 2). Była to największa liczba gatunków stwierdzona na lnie w okresie badań. Podobnie, jak w poprzednim roku nie stwierdzono różnic w liczebności pchełek pomiędzy poszczególnymi kombinacjami doświadczenia $(\mathrm{F}=0,269, \mathrm{df}=2, \mathrm{p} \leq 0,764)$. Niezależnie od modyfikacji genetycznej roślin zdecydowanym dominantem okazał się $A$. euphorbiae. W poszczególnych kombinacjach gatunek ten stanowił ponad 70\% wszystkich 
Tabela 1. Skład gatunkowy i liczebność pchełek zasiedlających trzy typy lnu w 2011 roku

Table 1. Species composition and abundance of flea beetles colonizing three types of linseed in 2011

\begin{tabular}{|c|c|c|c|c|c|c|c|c|}
\hline \multirow{2}{*}{ Gatunek - Species } & \multicolumn{2}{|c|}{$1^{*}$} & \multicolumn{2}{|c|}{2} & \multicolumn{2}{|c|}{3} & \multirow{2}{*}{ Suma - Total } & \multirow{2}{*}[\%]{} \\
\hline & $\mathrm{N}^{* *}$ & {$[\%]$} & $\mathrm{N}$ & {$[\%]$} & $\mathrm{N}$ & {$[\%]$} & & \\
\hline Aphthona euphorbiae (Schrank, 1781) & 925 & 91,9 & 661 & 91,9 & 900 & 89,7 & 2486 & 91,0 \\
\hline Longitarsus parvulus (Paykull, 1799) & 76 & 7,6 & 57 & 7,9 & 102 & 10,2 & 235 & 8,6 \\
\hline Phyllotreta vittula (Redtenbacher, 1849) & 3 & 0,3 & 1 & 0,1 & 1 & 0,1 & 5 & 0,2 \\
\hline Phyllotreta astrachanica Lopatin, 1977 & & & 1 & 0,1 & & & 1 & 0,1 \\
\hline Phyllotreta undulata (Kutschera, 1860) & 2 & 0,2 & & & & & 2 & 0,1 \\
\hline Suma - Total & 1006 & 100 & 720 & 100 & 1003 & 100 & 2729 & 100 \\
\hline Liczba gatunków - No. of species & \multicolumn{2}{|c|}{4} & \multicolumn{2}{|c|}{4} & \multicolumn{2}{|c|}{3} & \multicolumn{2}{|l|}{5} \\
\hline
\end{tabular}

*typy lnu - types of linseed: 1 - nadprodukujący flawonoidy - overproducing flavonoids, 2 - nadprodukujący glukozowe pochodne fenylopropanoidów - overproducing glucose derivatives of phenylpropanoid, 3 - rośliny kontrolne - control plants

**liczebność pchełek - number of flea beetles

Tabela 2. Skład gatunkowy i liczebność pchełek zasiedlających trzy typy lnu w 2012 roku

Table 2. Species composition and abundance of flea beetles colonizing three types of linseed in 2012

\begin{tabular}{|c|c|c|c|c|c|c|c|c|}
\hline \multirow{2}{*}{ Gatunek - Species } & \multicolumn{2}{|c|}{$1^{*}$} & \multicolumn{2}{|c|}{2} & \multicolumn{2}{|c|}{3} & \multirow{2}{*}{ Suma - Total } & \multirow{2}{*}[\%]{} \\
\hline & $\mathrm{N}^{* *}$ & {$[\%]$} & $\mathrm{N}$ & {$[\%]$} & $\mathrm{N}$ & {$[\%]$} & & \\
\hline Aphthona euphorbiae (Schrank, 1781) & 336 & 70,7 & 374 & 74,6 & 409 & 72,3 & 1119 & 72,6 \\
\hline Longitarsus parvulus (Paykull, 1799) & 117 & 24,6 & 112 & 22,4 & 137 & 24,3 & 366 & 23,7 \\
\hline Phyllotreta vittula (Redtenbacher, 1849) & 13 & 2,7 & 4 & 0,8 & 11 & 1,9 & 28 & 1,8 \\
\hline Phyllotreta astrachanica Lopatin, 1977 & 3 & 0,6 & 6 & 1,2 & 4 & 0,7 & 13 & 0,8 \\
\hline Phyllotreta undulata (Kutschera, 1860) & 4 & 0,8 & & & 2 & 0,3 & 6 & 0,4 \\
\hline Phyllotreta cruciferae (Goeze, 1777) & 1 & 0,2 & 2 & 0,4 & & & 3 & 0,2 \\
\hline Chaetocnema concinna (Marsham, 1802) & & & 2 & 0,4 & 2 & 0,3 & 4 & 0,2 \\
\hline Chaetocnema picipes Stephens, 1831 & 1 & 0,2 & 1 & 0,2 & 1 & 0,2 & 3 & 0,2 \\
\hline Chaetocnema aridula (Gyllenhal, 1827) & 1 & 0,2 & & & & & 1 & 0,1 \\
\hline Suma - Total & 476 & 100 & 501 & 100 & 566 & 100 & 1543 & 100 \\
\hline Liczba gatunków - No. of species & & & & & & & 9 & \\
\hline
\end{tabular}

*typy lnu - types of linseed: 1 - nadprodukujący flawonoidy - overproducing flavonoids, 2 - nadprodukujący glukozowe pochodne fenylopropanoidów - overproducing glucose derivatives of phenylpropanoid, 3 - rośliny kontrolne - control plants

**liczebność pchełek - number of flea beetles

oznaczonych stonek. W omawianym roku licznie reprezentowany był również L. parvulus. Udział tego gatunku w łącznej liczbie pchełek stwierdzonych w poszczególnych kombinacjach był zbliżony i wahał się od 22,4\% do 24,6\%. Zdecydowanie mniej licznie występowały Phyllotreta vittula i Phyllotreta astrachanica, których stwierdzono odpowiednio $1,8 \%$ oraz $0,8 \%$ wśród wszystkich odłowionych pchełek. Pozostałe pięć gatunków występowało sporadycznie.

W 2013 roku, w okresie rozwoju lnu wykonano 7 odłowów przy użyciu czerpaka entomologicznego. W odłowionym materiale stwierdzono łącznie 6268 pchełek oznaczonych do 7 gatunków (tab. 3). Była to największa liczba pchełek odłowiona $w$ ciągu trzech lat badań. Nie stwierdzono istotnych różnic w liczbie zebranych chrząszczy w zależności od zastosowanego typu genetycznie modyfikowanych roślin lnu oleistego $(\mathrm{F}=0,855$, df $=2$, $\mathrm{p} \leq 0,428)$. Liczba oznaczonych gatunków wahała się od 4 (typ 2 i typ 3 ) do 5 (typ 1). A. euphorbiae, podobnie jak $\mathrm{w}$ poprzednich latach, był zdecydowanie najliczniejszym gatunkiem, stanowiąc od 90,2\% (typ 3) do 92,3\% (typ 1) wszystkich odłowionych pchełek. Procentowy udział drugiego z liczniej odławianych na wszystkich typach $\operatorname{lnu}$ gatunku L. parvulus wynosił odpowiednio 7,4\% (typ 1), $8,7 \%$ (typ 2) i 9,5\% (typ 3). Przedstawiciele pozostałych oznaczonych gatunków występowali sporadycznie.

W ciągu trzech lat badań oznaczono łącznie we wszystkich kombinacjach lnu oleistego 11 gatunków pchełek. W każdym roku zdecydowanie najliczniejszym gatunkiem był $A$. euphorbiae. W znacznie mniejszym nasileniu występował L. parvulus. Wszystkie pozostałe gatunki odławiane na roślinach różnych typów lnu są gatunkami przypadkowymi, związanymi pokarmowo $\mathrm{z}$ chwastami lub innymi roślinami uprawnymi (Warchałowski 1995, 1998). Zurańska (1965a), w badaniach wykonanych w rejonie byłego województwa olsztyńskiego, stwierdziła na lnie 14 gatunków pchełek, natomiast Lakhmanov (1970), 15 innych gatunków pchełek. Żurańska (1965a) tylko dwa z nich uznaje za szkodniki (A. euphorbiae, L. parvulus), pozostałe natomiast za gatun- 
Tabela 3. Skład gatunkowy i liczebność pchełek zasiedlających trzy typy lnu w 2013 roku

Table 3. Species composition and abundance of flea beetles colonizing three types of linseed in 2013

\begin{tabular}{|c|c|c|c|c|c|c|c|c|}
\hline \multirow{2}{*}{ Gatunek - Species } & \multicolumn{2}{|c|}{$1 *$} & \multicolumn{2}{|c|}{2} & \multicolumn{2}{|c|}{3} & \multirow{2}{*}{ Suma - Total } & \multirow{2}{*}[\%]{} \\
\hline & $\mathrm{N}^{* *}$ & {$[\%]$} & $\mathrm{N}$ & {$[\%]$} & $\mathrm{N}$ & {$[\%]$} & & \\
\hline Aphthona euphorbiae (Schrank, 1781) & 2129 & 92,3 & 2086 & 91,1 & 1511 & 90,2 & 5726 & 91,3 \\
\hline Longitarsus parvulus (Paykull, 1799) & 171 & 7,4 & 200 & 8,7 & 159 & 9,5 & 530 & 8,4 \\
\hline Phyllotreta vittula (Redtenbacher, 1849) & 1 & 0,1 & 2 & 0,1 & 4 & 0,2 & 7 & 0,1 \\
\hline Phyllotreta undulata (Kutschera, 1860) & 1 & 0,1 & & & & & 1 & 0,05 \\
\hline Chaetocnema picipes Stephens, 1831 & & & 1 & 0,1 & & & 1 & 0,05 \\
\hline Phyllotreta nigripes (Fabricius, 1775) & & & & & 1 & 0,1 & 1 & 0,05 \\
\hline Phyllotreta striolata (Illiger, 1803) & 2 & 0,1 & & & & & 2 & 0,05 \\
\hline Suma - Total & 2304 & 100 & 2289 & 100 & 1675 & 100 & 6268 & 100 \\
\hline Liczba gatunków - No. of species & \multicolumn{2}{|c|}{5} & \multicolumn{2}{|c|}{4} & \multicolumn{2}{|c|}{4} & \multicolumn{2}{|l|}{7} \\
\hline
\end{tabular}

*typy lnu - types of linseed: 1 - nadprodukujący flawonoidy - overproducing flavonoids, 2 - nadprodukujący glukozowe pochodne fenylopropanoidów - overproducing glucose derivatives of phenylpropanoid, 3 - rośliny kontrolne - control plants

**liczebność pchełek - number of flea beetles

ki przypadkowe, niepowodujące szkód w badanym rejonie. Wskazuje również, że na tym samym terenie pchełka lnowa stanowiła około $80 \%$, a długostopka lnowa około $20 \%$ wszystkich oznaczonych pchełek. Proporcje te są bardzo zbliżone do tych uzyskanych w badaniach prowadzonych w okolicach Wrocławia w 2012 roku. W pozostałych latach badań $(2011,2013)$ procentowy udział A. euphorbiae w łącznej liczbie pchełek stwierdzonych w poszczególnych kombinacjach był wyższy (około 90\%). Zmniejszył się natomiast procentowy udział L. parvulus (7-10\% wszystkich pchełek). Nie stwierdzono wpływu modyfikacji genetycznej roślin lnu oleistego na liczebność i skład gatunkowy pchełek.

Dynamika populacji. W 2011 roku, pierwsze pojedyncze pchełki odłowiono do czerpaka w połowie maja (rys. 1a). We wszystkich badanych typach lnu rośliny były w tym czasie w fazie BBCH 30 (początek wzrostu pędu). W drugiej połowie maja oraz w czerwcu liczba odławianych pchełek utrzymywała się na podobnym poziomie w poszczególnych kombinacjach. Zwłaszcza w czerwcu widoczna była tendencja do liczniejszego występowania tych owadów na roślinach kontrolnych lnu (typ 3). W końcu czerwca i w pierwszych dniach lipca nastąpił wzrost liczby odławianych chrząszczy. W ostatnich odłowach wykonanych w końcu drugiej dekady lipca (BBCH 83 - dojrzałość wczesnożółta) stwierdzono maksymalny pojaw pchełek. Można sądzić, że w tym okresie pojawiły się osobniki pokolenia letniego. W dwóch ostatnich terminach pobierania prób stwierdzono istotne różnice w liczbie odłowionych pchełek w poszczególnych kombinacjach. Na początku lipca istotnie więcej owadów wystąpiło na roślinach kontrolnych $\mathrm{w}$ porównaniu do roślin nadprodukujących glukozowe pochodne fenylopropanoidów (typ 2). W ostatnim terminie najwięcej pchełek odłowiono na roślinach typu 1 (759), mniej na roślinach kontrolnych (571), natomiast najmniej na roślinach typu 2 (503).

Udział procentowy dwóch dominujących w 2011 roku gatunków pchełek, tj. A. euphorbiae oraz L. parvulus przedstawiono na rysunku $1 \mathrm{~b}$. Pierwsze pchełki pojawiły się na lnie 12 maja i byli to wyłącznie przedstawiciele L. parvulus (typ 2). W pozostałych 5 terminach odłowów, w każdej kombinacji doświadczenia, zdecydowanie większy udział miał $A$. euphorbiae.

W 2012 roku, liczne zimujące chrząszcze pchełek stwierdzono już w pierwszych odłowach, wykonanych w połowie maja na roślinach będących w początkowej fazie wzrostu pędu (BBCH 30) (rys. 2a). W połowie czerwca, w okresie pełni kwitnienia lnu odnotowano pierwsze, mniejsze maksimum liczebności populacji tych owadów (BBCH 65). W tym terminie nie odnotowano istotnych różnic $\mathrm{w}$ liczebności pchełek między badanymi kombinacjami. Po niewielkim załamaniu się liczebności populacji w trzeciej dekadzie czerwca, w połowie lipca miał miejsce kolejny maksymalny pojaw pchełek, tym razem pokolenia letniego $(\mathrm{BBCH} 83)$. W terminie tym istotnie więcej pchełek oznaczono $\mathrm{w}$ materiale zebranym z poletek, na których uprawiano rośliny typu 3 (174) w porównaniu do roślin typu 2 (142). Podobnie w trakcie ostatniego odłowu wykonanego w ostatniej dekadzie lipca istotnie więcej pchełek stwierdzono na poletkach roślin kontrolnych lnu w porównaniu do pozostałych kombinacji.

W 2012 roku, we wszystkich terminach odłowów stwierdzono występowanie dwóch najliczniejszych gatunków pchełek (rys. 2b). Niezależnie od kombinacji doświadczenia, w większości terminów zdecydowanie większy udział miał $A$. euphorbiae (od 70 do 95\%) w porównaniu do L. parvulus. Wyjątkowo w jednym terminie, tj. 28 czerwca, w każdej $\mathrm{z}$ trzech kombinacji oznaczono więcej L. parvulus (55-68\%).

W 2013 roku, odłowy przy użyciu czerpaka entomologicznego rozpoczęto na początku trzeciej dekady maja, kiedy len był w fazie BBCH 30 (rys. 3a). W pierwszej połowie czerwca liczba przedstawicieli stonkowatych wzrastała i osiągnęła pierwsze, mniejsze maksimum w połowie tego miesiąca na roślinach będących w początkowej fazie kwitnienia (BBCH 60-61). W okresie tego maksimum istotnie więcej chrząszczy stwierdzono na roślinach typu 2 i typu $3 \mathrm{w}$ porównaniu do roślin typu 3. Drugi, znacznie większy wzrost liczebności populacji miał miejsce $\mathrm{w}$ trzeciej dekadzie lipca (BBCH 83). Podobnie, jak 
a) pchełki łącznie - all flea beetles

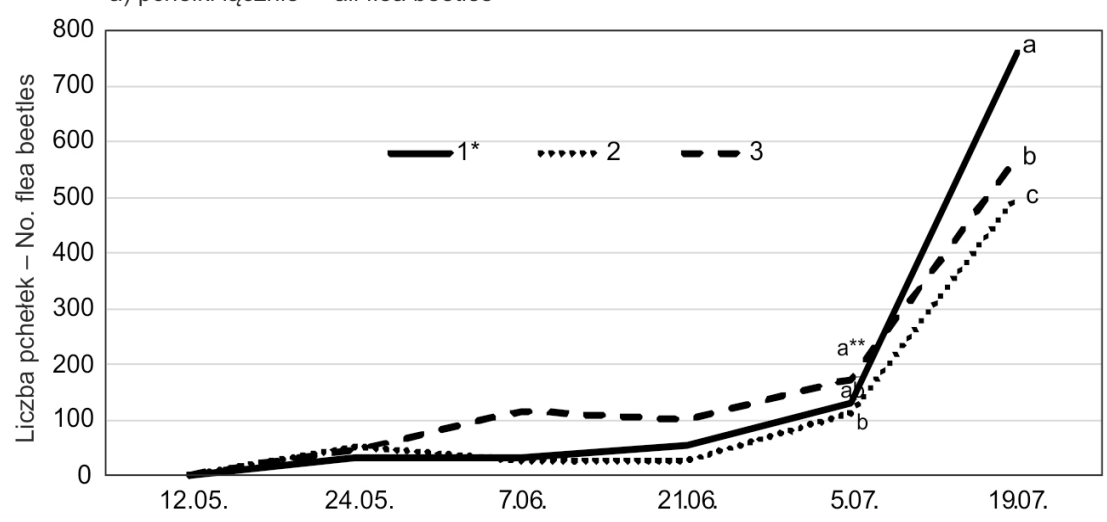

b) udział procentowy najliczniejszych gatunków - percentage of most abundant species

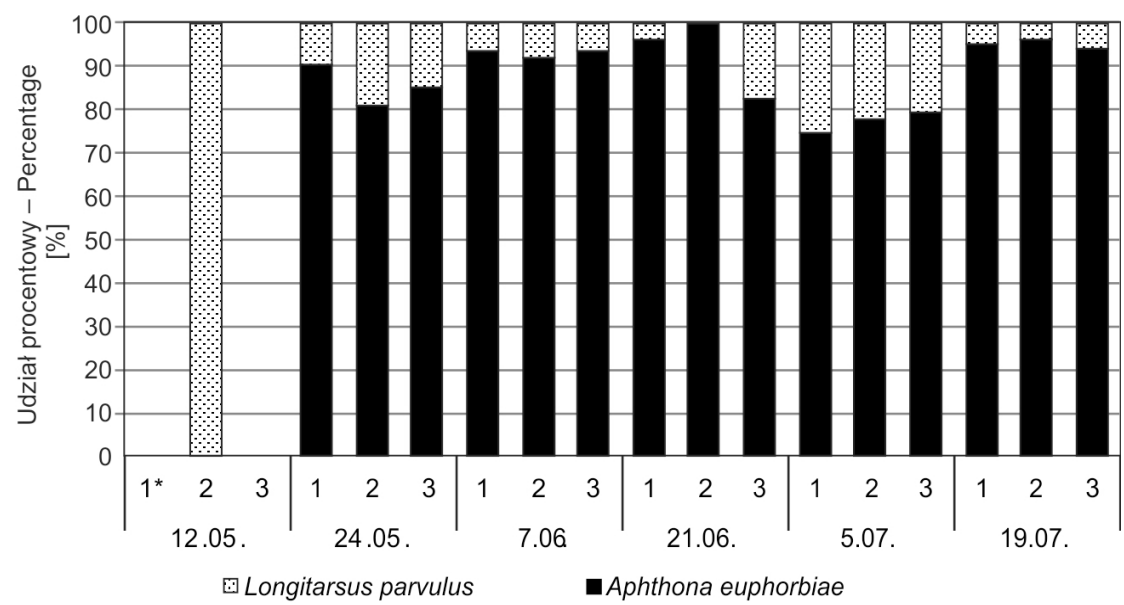

*typy Inu - types of linseed: 1 - nadprodukujący flawonoidy - overproducing flavonoids,

2 - nadprodukujący glukozowe pochodne fenylopropanoidów - overproducing glucose derivatives

of phenylpropanoid, 3 - rośliny kontrolne - control plants

** różnice istotne - significant differences

Rys. 1. Dynamika występowania pchełek na trzech typach lnu oleistego w 2011 roku

Fig. 1. Seasonal dynamics of flea beetles on three types of linseed in 2011

w przypadku pierwszego maksimum, więcej pchełek występowało na lnie modyfikowanym genetycznie typu 1 (928) i typu 2 (810) niż na lnie odmiany kontrolnej Linola (549). W omawianym sezonie wegetacyjnym ostatnie pchełki odławiano na początku sierpnia, kiedy rośliny osiągnęły pełną dojrzałość (BBCH 89).

W 2013 roku, we wszystkich terminach odłowów pchełek, we wszystkich kombinacjach doświadczenia, zdecydowanie liczniejszym gatunkiem był A. euphorbiae (rys. 3b). Udział procentowy tego gatunku stanowił $70-98 \% \mathrm{w}$ porównaniu do L. parvulus.

We wszystkich badanych typach lnu stwierdzono dwa okresy licznego występowania pchełek, tj. mniej liczne, zwykle w drugiej dekadzie czerwca, tworzone przez zimujące osobniki oraz większe w drugiej połowie lipca tworzone przez chrząszcze pokolenia letniego. W badaniach prowadzonych $\mathrm{w}$ latach 50. ubiegłego wieku, podobne dwa maksima liczebności pchełek zaobserwowała Żurańska (1965b).

Uszkodzenia roślin. Każdego roku liczba wyżerek powodowanych przez pchełki na liściach, łodygach i torebkach lnu różniła się w poszczególnych kombinacjach i w poszczególnych datach odłowów. W 2011 roku, pierwsze uszkodzenia powodowane przez chrząszcze stwierdzono na młodych roślinach (BBCH 19) w trzeciej dekadzie maja (rys. 4). Największa liczba wyżerek na roślinach wszystkich typów lnu odnotowana została w pierwszej i drugiej dekadzie czerwca. W tym terminie zimujące chrząszcze żerowały głównie na roślinach będących w końcowym okresie rozwoju kwiatostanu oraz $\mathrm{w}$ okresie kwitnienia (BBCH 59-69). W trakcie późniejszych obserwacji liczba uszkodzeń stopniowo zmniejszała się. Pomimo, że pchełki nowego pokolenia występowały najliczniej w końcowym okresie rozwoju lnu, to liczba wyżerek obserwowana w tym czasie była niewielka. Len był wówczas w fazie dojrzewania owoców i nasion, zatem owady nie żerowały już na takich roślinach. W okresie wegetacji lnu, w trakcie czterech obserwacji na osiem, stwierdzono istotnie mniej wyżerek na roślinach nadprodukujących flawonoidy (typ 1) w porównaniu do liczby wyżerek na lnie odmiany kontrolnej Linola (typ 3). Na roślinach o zwiększonej zawartości glukozowych pochodnych fenylopropanoidów (typ 2) liczba uszkodzeń była zbliżona do tych obserwowanych na roślinach o zwiększonej zawartości flawonoidów. 
a) pchełki łącznie - all flea beetles

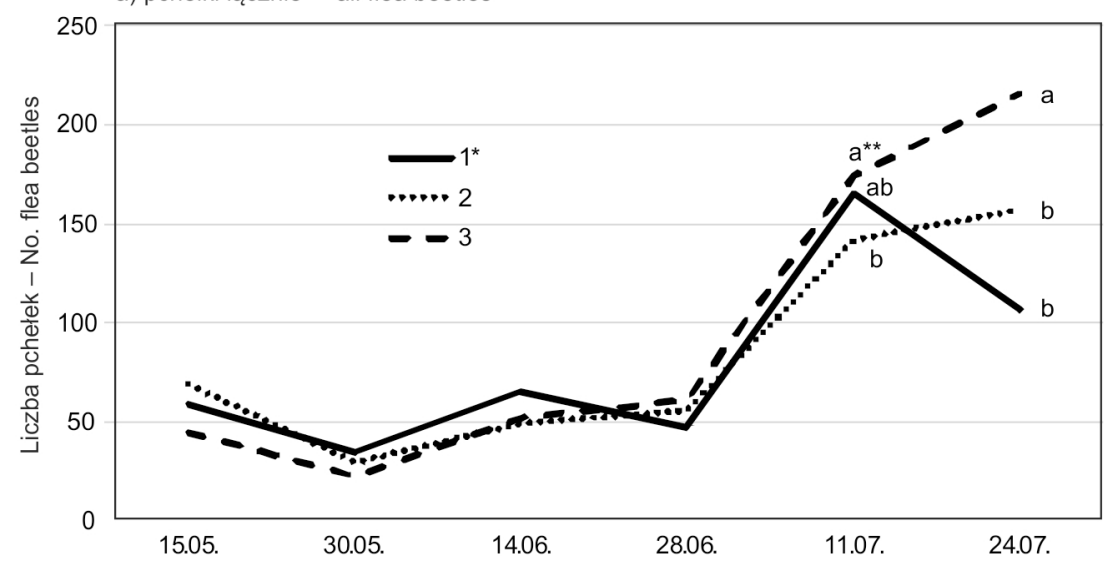

b) udział procentowy najliczniejszych gatunków - percentage of most abundant species

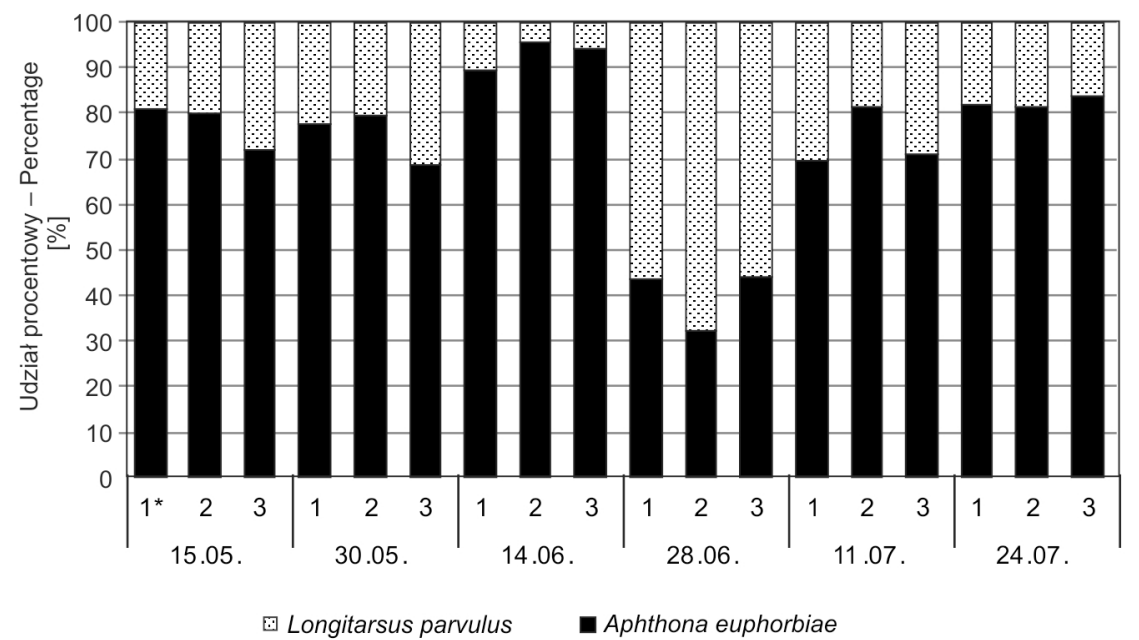

*typy Inu - types of linseed: 1 - nadprodukujący flawonoidy - overproducing flavonoids,

2 - nadprodukujący glukozowe pochodne fenylopropanoidów - overproducing glucose derivatives

of phenylpropanoid, 3 - rośliny kontrolne - control plants

**óżnice istotne - significant differences

Rys. 2. Dynamika występowania pchełek na trzech typach lnu oleistego w 2012 roku

Fig. 2. Seasonal dynamics of flea beetles on three types of linseed in 2012

W 2012 roku, liczne objawy żerowania pchełek obserwowano już na początku maja na młodych roślinach wszystkich typów lnu będących w fazie 8-9 liści (BBCH 18-19) (rys. 5). Duża liczba uszkodzeń stwierdzana była szczególnie od połowy maja do pierwszych dni czerwca, czyli w okresie wzrostu pędu głównego do pełni kwitnienia (BBCH 30-65). W drugiej połowie czerwca i w lipcu liczba wyżerek stopniowo zmniejszała się. W omawianym roku uzyskano odmienne wyniki w porównaniu do tych z 2011 roku. Na jedenaście wykonanych obserwacji, w ośmiu przypadkach istotnie mniej uszkodzeń odnotowano na roślinach typu $3 \mathrm{w}$ porównaniu do uszkodzeń na roślinach typu 1. Liczba uszkodzeń na roślinach typu 2 była często pośrednia do tej odnotowanej na roślinach dwóch pozostałych typów.

W 2013 roku, pierwsze objawy żerowania zimujących chrząszczy stwierdzono na bardzo małych roślinach (BBCH 11-13) w połowie ostatniej dekady maja (rys. 6). W końcu maja liczba uszkodzeń zaczęła wzrastać na roślinach wszystkich kombinacji, a maksymalne ich występowanie stwierdzono w pierwszej połowie czerwca. Najliczniejsze wyżerki odnotowywano na roślinach będących w fazie BBCH 30-60. W drugiej połowie czerwca i w lipcu intensywność żerowania pchełek spadała. Jednym z czynników ograniczających żerowanie pojawiających się chrząszczy nowego pokolenia było dojrzewanie roślin. W trakcie czterech obserwacji, na siedem wykonanych, istotnie mniej wyżerek występowało na roślinach o zwiększonej zawartości flawonoidów (typ 1) w porównaniu do roślin kontrolnych (typ 3). Jednocześnie w trakcie pierwszej i ostatniej analizy uzyskano odmienne wyniki, tzn. mniej uszkodzeń stwierdzono na roślinach kontrolnych w porównaniu do dwóch pozostałych typów. Podobnie, jak w roku poprzednim, liczba uszkodzeń na roślinach o zwiększonej zawartości glukozowych pochodnych fenylopropanoidów (typ 2) była często pośrednia do tej stwierdzanej na roślinach dwóch pozostałych typów. 
a) pchełki łącznie - all flea beetles

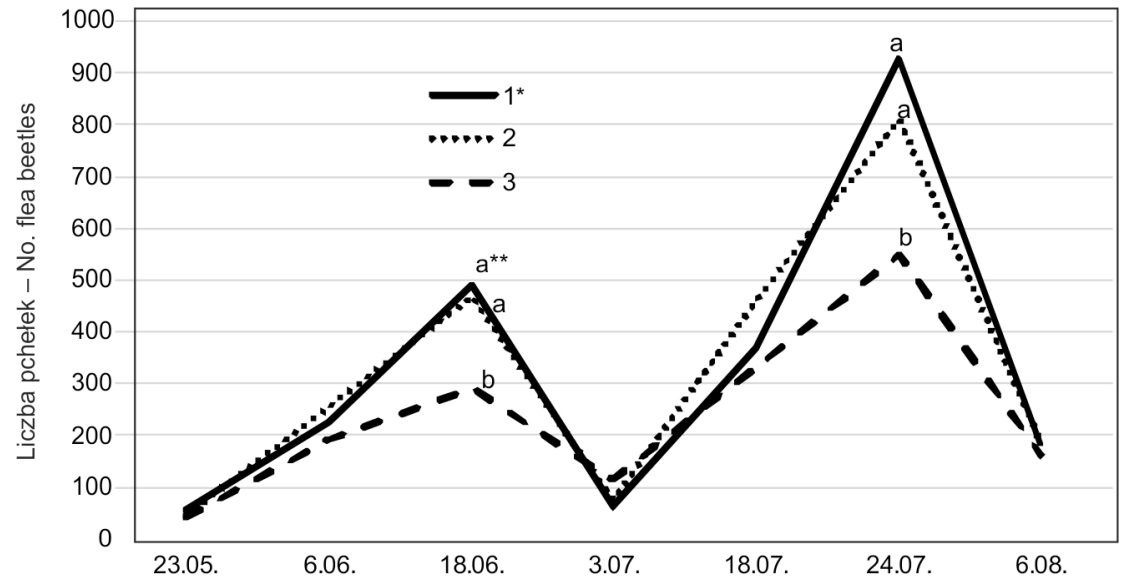

b) udział procentowy najliczniejszych gatunków - percentage of most abundant species

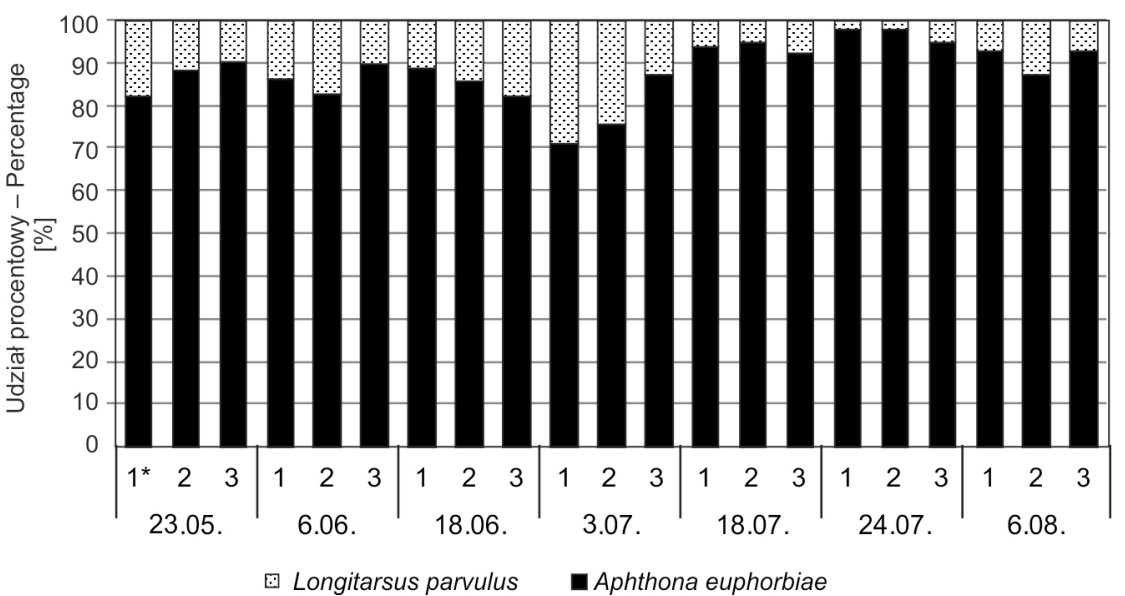

*typy Inu - types of linseed: 1 - nadprodukujący flawonoidy - overproducing flavonoids,

2 - nadprodukujący glukozowe pochodne fenylopropanoidów - overproducing glucose derivatives

of phenylpropanoid, 3 - rośliny kontrolne - control plants

** różnice istotne - significant differences

Rys. 3. Dynamika występowania pchełek na trzech typach lnu oleistego w 2013 roku

Fig. 3. Seasonal dynamics of flea beetles on three types of linseed in 2013

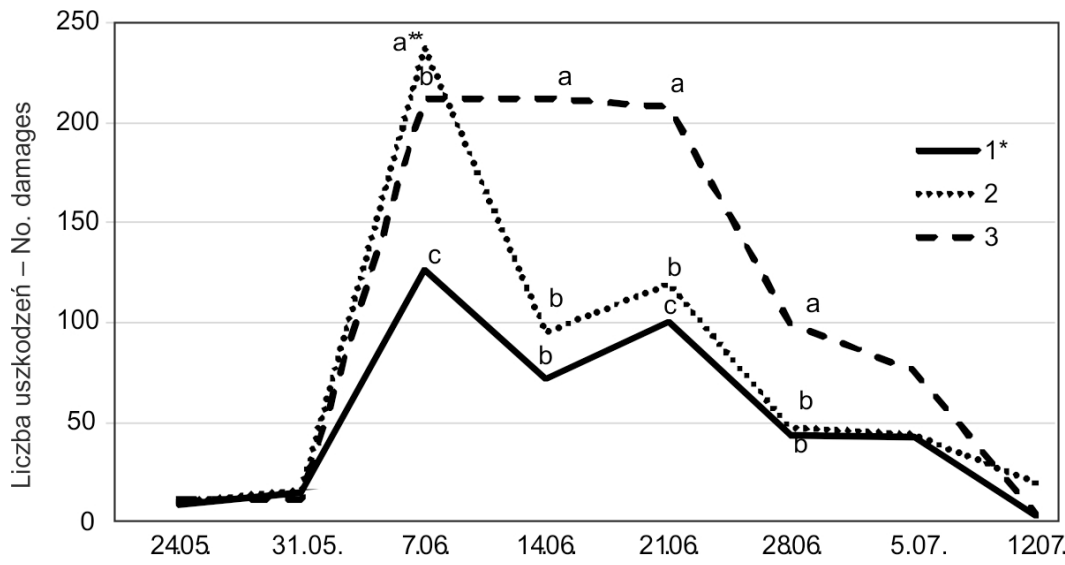

*typy Inu - types of linseed: 1 - nadprodukujący flawonoidy - overproducing flavonoids,

2 - nadprodukujący glukozowe pochodne fenylopropanoidów - overproducing glucose derivatives of phenylpropanoid, 3 - rośliny kontrolne - control plants

** różnice istotne - significant differences

Rys. 4. Liczba uszkodzeń powodowanych przez pchełki na trzech typach lnu oleistego w 2011 roku

Fig. 4. Number of damages caused by flea beetles on three types of linseed in 2011 


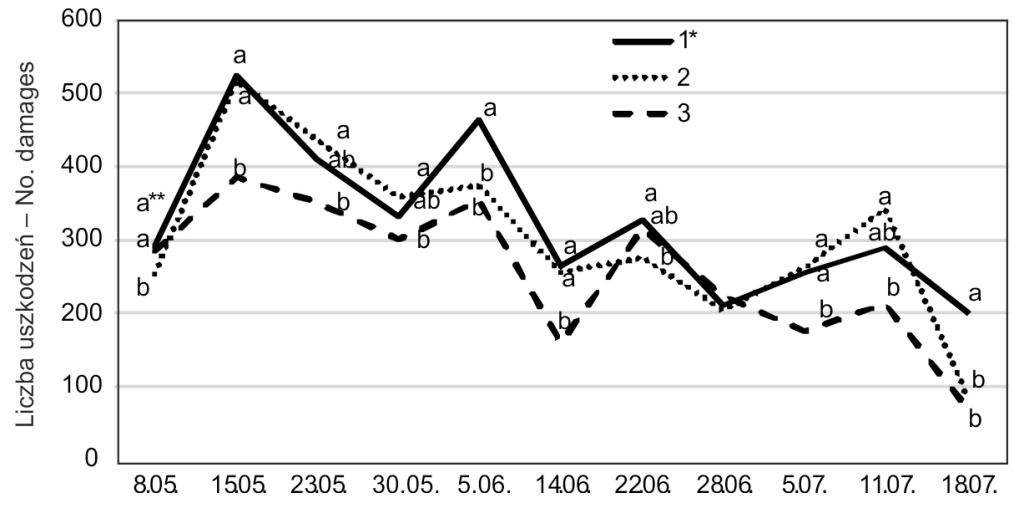

*typy Inu - types of linseed: 1 - nadprodukujący flawonoidy - overproducing flavonoids,

2 - nadprodukujący glukozowe pochodne fenylopropanoidów - overproducing glucose derivatives of phenylpropanoid, 3 - rośliny kontrolne - control plants

**óżżice istotne - significant differences

Rys. 5. Liczba uszkodzeń powodowanych przez pchełki na trzech typach lnu oleistego w 2012 roku

Fig. 5. Number of damages caused by flea beetles on three types of linseed in 2012

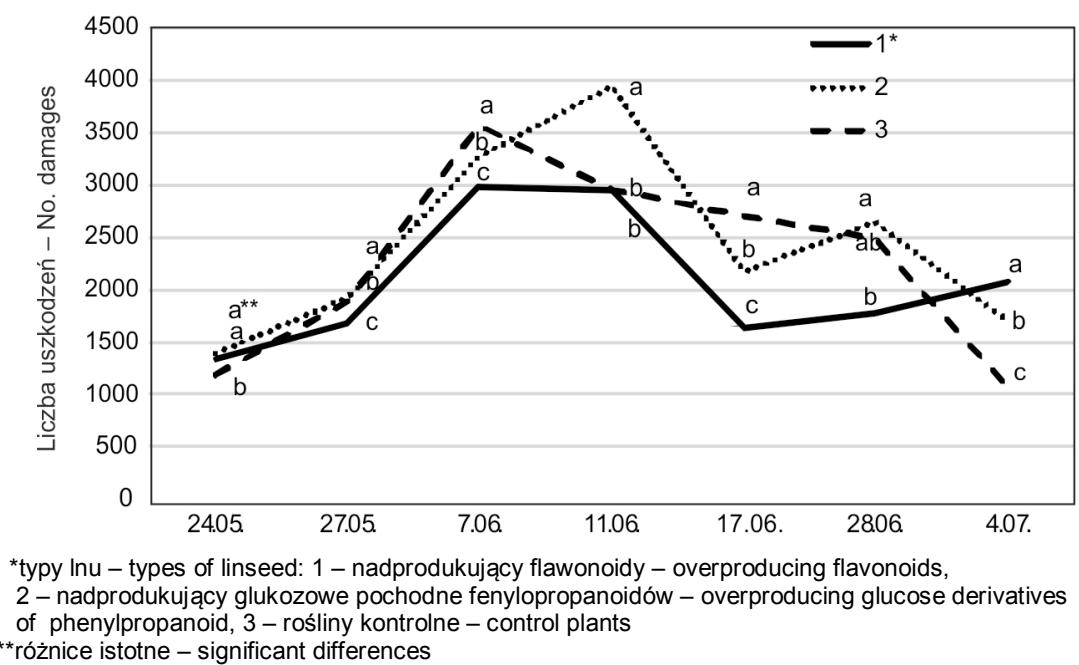

Rys. 6. Liczba uszkodzeń powodowanych przez pchełki na trzech typach lnu oleistego w 2013 roku

Fig. 6. Number of damages caused by flea beetles on three types of linseed in 2013

W piśmiennictwie znanych jest wiele przykładów, w których flawonoidy ograniczają liczebność, żerowanie i rozwój różnych grup fitofagów (Stamp i Horwath 1992; Hoffman-Campo i wsp. 2001; Musabyimana i wsp. 2001; Simmonds 2003; Diaz Napal i wsp. 2010; Ateyyat i wsp. 2012; Jadhav i wsp. 2012). Przeprowadzone badania dotyczące pchełek nie potwierdzają tej prawidłowości, bowiem uzyskane wyniki nie są w pełni jednoznaczne. W ciągu 3 lat badań, w dynamice występowania pchełek istotne różnice stwierdzono zarówno na roślinach kontrolnych lnu, jak i na roślinach genetycznie modyfikowanych. Podobnie, niejednoznaczne wyniki uzyskano w przypadku badań dotyczących uszkodzeń powodowanych przez pchełki. W pierwszym i trzecim roku stwierdzono więcej przypadków redukcji liczby uszkodzeń na roślinach nadprodukujących flawonoidy $\mathrm{w}$ porównaniu do roślin kontrolnych lnu. W drugim roku badań uzyskano jednak odmienne wyniki, gdy w większości przypadków stwierdzono mniej wyżerek na roślinach kontrolnych.

\section{Wnioski / Conclusions}

1. W ciągu trzech lat badań prowadzonych na roślinach dwóch typów genetycznie modyfikowanego lnu oleistego, odmiana Linola oraz na roślinach kontrolnych tej odmiany, oznaczono łącznie 11 gatunków pchełek. W każdym roku zdecydowanie najliczniejszym gatunkiem, niezależnie od kombinacji był $A$. euphorbiae. W znacznie mniejszym nasileniu występował $L$. parvulus.

2. Nie stwierdzono jednoznacznego wpływu modyfikacji genetycznej lnu oleistego polegającej na nadprodukcji flawonoidów czy nadprodukcji glukozowych pochodnych fenylopropanoidów na skład gatunkowy i liczebność pchełek. Nie stwierdzono też redukującego wpływu tych modyfikacji na dynamikę populacji i liczbę uszkodzeń powodowanych przez omawiane szkodniki. 


\section{Podziękowania / Acknowledgements}

Praca wykonana $\mathrm{w}$ ramach projektu badawczego $\mathrm{nr}$ 2017110/2011 finansowanego przez Narodowe Centrum
Badań i Rozwoju. Składamy podziękowania mgr Joannie Magierze-Dulewicz za pomoc przy zestawianiu wyników badań.

\section{Literatura / References}

Ateyyat M., Abu-Romman S., Abu-Darwish M., Ghabeish I. 2012. Impact of flavonoids against woolly apple aphid, Eriosoma lanigerum (Hausmann) and its parasitoid, Aphelinus mali (Hald.). Journal of Agricultural Science 4 (2): 227-236.

Borowiec L., Ścibior R., Kubisz D. 2011. Critical check-list of the Polish Chrysomeloidea, except Cerambycidae (Coleoptera: Phytophaga). Genus 22 (4): 579-608.

Czemplik M., Kulma A., Bazela K., Szopa J. 2012. The biomedical potential of genetically modified flax seeds overexpressing the glucosyltransferase gene. BMC Complementary and Alternative Medicine 12: 251. DOI: 10.1186/1472-6882-12-251.

Diaz Napal G.N., Defago M.T., Valladares G.R., Palacios S.M. 2010. Response of Epilachna paenulata to two flavonoids, pinocembrin and quercetin, in a comparative study. Journal of Chemical Ecology 36 (8): 898-904.

Ferguson A.W., Bruce D.L., Wiliams I.H. 1997. Insect injury to linseed in south-east England. Crop Protection 16 (7): 643-652.

Fritzsche R., Lehmann H. 1975. Effect of micro-climate on the feeding activity of flax flea beetles. Archiv für Phytopathologie und Pflanzenschutz 11 (2): 153-159.

Heller K. 2013. Crop management of fibre flax in Europe. FIBRA Summer School, Catania, Italy, 21-27 July 2013 , 96 pp.

Heller K., Andruszewska A., Grabowska L., Wielgusz K. 2006. Ochrona lnu i konopi w Polsce i na świecie. [Fibre flax and hemp protection in Poland and in the world]. Progress in Plant Protection/Postępy w Ochronie Roślin 46 (1): 88-98.

Hoffman-Campo C.B., Harborne J.B., McCaffery A.R. 2001. Pre-ingestive and post-ingestive effects of soya bean extracts and rutin on Trichoplusia ni growth. Entomologia Experimentalis et Applicata 98 (2): 181-194.

Horak A. 1991. Strategies for control of flax flea beetles (Aphthona euphorbiae), (Longitarsus parvulus) in linseed in Czechoslovakia. Aspects of Applied Biology 28: 133-136.

Jadhav D.R., Mallikarjuna N., Rathore A., Pokle D. 2012. Effect of some flavonoids on survival and development of Helicoverpa armigera (Hübner) and Spodoptera litura (Feb) (Lepidoptera: Noctuidae). Asian Journal of Agricultural Sciences 4 (4): 298-307.

Korkina L.G. 2007. Phenylpropanoids as naturally occurring antioxidants: from plant defense to human health. Cell and Molecular Biology 53 (1): 15-25.

Lakhmanov V.P. 1970. The injuriousness of the yellow spurge flea beetle. Zashchita Rastenii 15, p. 10.

Lewartowski R., Piekarczyk K. 1978. Charakterystyka rozwoju, występowania i szkodliwości ważniejszych szkodników roślin przemysłowych w 1975 roku w Polsce. Biuletyn Instytutu Ochrony Roślin 62: 151-221.

Linkiewicz A., Dąbrowski Z.T., Sowa S. 2012. Genetically modified plants - from the laboratory to practical application in European agriculture. Part I. Chemik 66 (8): 843-855.

Mohr K.H. 1966. Chrysomelidae. p. 95-299. In: “Die Kafer Mitteleuropas, Band 9” (H. Freude, K. Harde, G.A. Lohse, eds.). Krefeld, Germany, $299 \mathrm{pp}$.

Musabyimana T., Saxena R.C., Kaimu E.W., Ogol C.P.K.O., Khan Z.R. 2001. Effects of neem seed derivatives on behavioral and physiological responses of the Cosmopolites sordidus (Coleoptera: Curculionidae). Journal of Economical Entomology 94 (2): 449-454.

Nap J.-P., Metz P.L.J., Escaler M., Conner A.J. 2003. The release of genetically modified crops into the environment. The Plant Journal 33 (1): $1-18$.

Simmonds M.S.J. 2003. Flavonoid-insect interactions: Recent advances in our knowledge. Phytochemistry 64 (1): 21-30.

Simmonds M.S.J., Blaney W.M., Fellows L.E. 1990. Behavioral and electrophysiological study of antifeedant mechanisms associated with polyhydroxyalkaloids. Journal of Chemical Ecology 16 (11): 3167-3196.

Stamp N.E., Horwath K.L. 1992. Interactive effects of temperature and concentrations of the flavonol rutin on growth, moult and food utilization of Manduca sexta caterpillars. Entomologia Experimentalis et Applicata 64: 135-150.

Stolarzewicz I.A., Ciekot J., Fabiszewska A.U., Białecka-Florjańczyk E. 2013. Roślinne i mikrobiologiczne źródła przeciwutleniaczy. [Plant and microbial sources of antioxidants]. Postępy Higieny i Medycyny Doświadczalnej 67: 1359-1373.

Treutter D. 2006. Significance of flavonoids in plant resistance: a review. Environmental Chemistry Letters 4 (3): $147-157$.

War A.R., Paulraj M.G., Ahmad T., Buhroo A.A., Hussain B., Ignacimuthu S., Sharma H.C. 2012. Mechanisms of plant defense against insect herbivores. Plant Signal Behavior 7 (10): 1306-1320.

Warchałowski A. 1978. Stonkowate - Coleoptera. Podrodziny: Halticinae, Hispinae i Cassidinae. Klucze do oznaczania owadów Polski. XIX, 94c. Państwowe Wydawnictwo Naukowe, Warszawa, 157 ss.

Warchałowski A. 1995. Chrysomelidae. Stonkowate (Insecta: Coleoptera). Część V (podrodzina: Halticinae: rodzaje Phyllotreta, Aphthona i Longitarsus). Fauna Polski, 17. Muzeum i Instytut Zoologii Polskiej Akademii Nauk, Warszawa, 360 ss.

Warchałowski A. 1998. Chrysomelidae. Stonkowate (Insecta: Coleoptera). Część VI (podrodzina: Halticinae: rodzaje HermaeophagaDibolia). Fauna Polski, 20. Polskie Towarzystwo Entomologiczne, Warszawa, 292 ss.

Wise I.L., Soroka J.J. 2003. Principal insect pests of flax. p. 142-145. In: "Flax the Genus Linum" (A.D. Muir, N.D. Westcott, eds.). Routlege Taylor and Francis Ltd, London and New York.

Zuk M., Kulma A., Dyminska L., Szoltysek K., Prescha A., Hanuza J., Szopa J. 2011. Flavonoid engineering of flax potentiate its biotechnological application. BMC Biotechnology 11: 10. DOI: 10.1186/1472-6750-11-10.

Żurańska I. 1965a. Pchełki (Halticinae) występujące na uprawach lnu w województwie olsztyńskim i ich gospodarcze znaczenie. Zeszyty Naukowe Wyższej Szkoły Rolniczej w Olsztynie 19: 475-483.

Żurańska I. 1965b. Dynamika występowania Aphthona euphorbiae Schr. i Longitarsus parvulus Payk. na uprawach lnu w województwie olsztyńskim w zależności od niektórych czynników ekologicznych. Zeszyty Naukowe Wyższej Szkoły Rolniczej w Olsztynie 19: 485-489. 